\title{
Article
}

\section{Water Needs of Willow (Salix L.) in Western Poland}

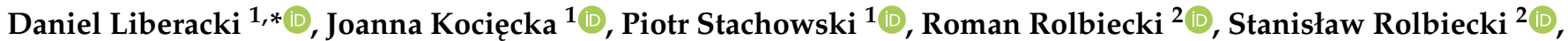 \\ Hicran A. Sadan ${ }^{2}$, Anna Figas ${ }^{3}{ }^{\circ}$, Barbara Jagosz ${ }^{4}{ }^{\circledR}$, Dorota Wichrowska ${ }^{5}{ }^{\circledR}$, Wiesław Ptach ${ }^{6}$, Piotr Prus ${ }^{7} \mathbb{D}^{\circ}$, \\ Ferenc Pal-Fam ${ }^{8}$ iD and Ariel Łangowski ${ }^{2}$
}

check for updates

Citation: Liberacki, D.; Kocięcka, J.; Stachowski, P.; Rolbiecki, R.; Rolbiecki, S.; Sadan, H.A.; Figas, A.; Jagosz, B.; Wichrowska, D.; Ptach, W.; et al. Water Needs of Willow (Salix L.) in Western Poland. Energies 2022, 15, 484. https://doi.org/10.3390/ en15020484

Academic Editors: Vitaliy Krupin, Roman Podolets and Alban Kuriqi

Received: 1 December 2021

Accepted: 5 January 2022

Published: 11 January 2022

Publisher's Note: MDPI stays neutral with regard to jurisdictional claims in published maps and institutional affiliations.

Copyright: (C) 2022 by the authors. Licensee MDPI, Basel, Switzerland. This article is an open access article distributed under the terms and conditions of the Creative Commons Attribution (CC BY) license (https:// creativecommons.org/licenses/by/ $4.0 /)$.
1 Department of Land Improvement, Environmental Development and Spatial Management, Faculty of Environmental Engineering and Mechanical Engineering, Poznan University of Life Sciences, 60-649 Poznan, Poland; joanna.kociecka@up.poznan.pl (J.K.); piotr.stachowski@up.poznan.pl (P.S.)

2 Department of Agrometeorology, Plant Irrigation and Horticulture, Faculty of Agriculture and Biotechnology, Bydgoszcz University of Science and Technology, 85-029 Bydgoszcz, Poland; rolbr@pbs.edu.pl (R.R.); rolbs@pbs.edu.pl (S.R.); hicran_sadan_76@hotmail.com (H.A.S.); arilan000@pbs.edu.pl (A.Ł.)

3 Department of Agricultural Biotechnology, Faculty of Agriculture and Biotechnology, Bydgoszcz University of Science and Technology, 85-029 Bydgoszcz, Poland; figasanna@pbs.edu.pl

4 Department of Plant Biology and Biotechnology, Faculty of Biotechnology and Horticulture, University of Agriculture in Krakow, 31-120 Krakow, Poland; Barbara.Jagosz@urk.edu.pl

5 Department of Microbiology and Food Technology, Faculty of Agriculture and Biotechnology, Bydgoszcz University of Science and Technology, 85-029 Bydgoszcz, Poland; wichrowska@pbs.edu.pl

6 Department of Remote Sensing and Environmental Research, Institute of Environmental Engineering, Warsaw University of Life Sciences, 02-776 Warsaw, Poland; wieslaw_ptach@sggw.edu.pl

7 Department of Agronomy, Faculty of Agriculture and Biotechnology, Bydgoszcz University of Science and Technology, 85-029 Bydgoszcz, Poland; piotr.prus@pbs.edu.pl

8 Institute of Plant Production, Kaposvár Campus, Hungarian University of Agriculture and Life Sciences (MATE), H-7400 Kaposvar, Hungary; Pal-Fam.Ferenc.Istvan@szie.hu

* Correspondence: daniel.liberacki@up.poznan.pl

Abstract: Willows are one of the plants which can be used to produce biomass for energy purposes. Biomass production is classified as a renewable energy source. Increasing the share of renewable sources is one of the priority actions for European Union countries due to the need to reduce greenhouse gas emissions. To achieve the best possible growth of the willow and increase its biomass for fuel, it is crucial to provide optimal water conditions for its growth. The aim of the study was to determine the water requirements of willows under the conditions of the western Polish climate and to verify whether this area is potentially favourable for willow cultivation. The novelty of this paper lies in its multi-year climatic analysis in the context of willow water needs for the area of three voivodships: Lubusz, Lower Silesian, and West Pomeranian. This is one of the few willow water-needs analyses for this region which considers the potential for widespread willow cultivation and biomass production in western Poland. Reference evapotranspiration (ETo) was determined by the Blaney-Criddle equation and then, using plant coefficients, water needs for willow were determined. Calculations were carried out for the growing season lasting from 21 May to 31 October. The estimated water needs during the vegetation season amounted on average to $408 \mathrm{~mm}$ for the West Pomeranian Voivodeship, $405 \mathrm{~mm}$ for the Lubusz Voivodeship, and $402 \mathrm{~mm}$ for the Lower Silesian Voivodeship. The conducted analysis of variance (ANOVA) showed that these needs do not differ significantly between the voivodeships. Therefore, it can be concluded that the water requirements of willows in western Poland do not differ significantly, and the whole region shows similar water conditions for willow cultivation. Furthermore, it was found that water needs are increasing from decade to decade, making rational water management necessary. This is particularly important in countries with limited water resources, such as Poland. Correctly determining the water requirements of willow and applying them to the cultivation of this plant should increase the biomass obtained. With appropriate management, willow cultivation in Poland can provide an alternative energy source to coal. 
Keywords: willow; Salix L.; water needs; biomass; evapotranspiration; energy crops; precipitation deficit

\section{Introduction}

One of the priority strategies of the European Union is "Climate Neutral by 2050". This document assumes reducing greenhouse gas emissions by the Member States and striving for climate neutrality (i.e., zero emissions). The implementation of this task focuses, among other things, on the use of alternative sources of energy to eliminate conventional fuels. This is particularly important in Poland, where most energy comes from burning fossil fuels. In 2019, the share of renewable energy in gross final energy consumption in this country was only $12.2 \%$ [1]. This is one of the lower results concerning the European Union countries. One of the ways to improve the current situation is to replace classical energy sources with biofuels created from biomass. Biomass can be obtained from energy crops. The energy plants cultivated in the conditions of Polish climate include poplar (Populus L.), Robinia acacia (Robinia pseudoacacia L.), Virginia fanpetals (Sida hermaphrodita), Jerusalem artichoke (Helianthus tuberosus), Giant miscanthus (Miscanthus $\times$ giganteus), and willows (Salix L.).

The willow is a plant that is easy to reproduce and overgrows. The willow comprises more than 300 species that occur as trees, shrubs, or dwarf shrubs. It has low soil requirements but broadly responds to habitat conditions, especially water conditions and organic and mineral fertilization [2]. Salix tolerates moist habitats, and its cultivation is not complicated. It usually occupies clay soils with poor permeability and difficult groundwater recharge [3]. Researchers highlight that the willow is a cleaner energy source than fossil fuels and one of the most promising biomass fuels [4]. According to Heinsoo [5], under moderate climate conditions, annual woody biomass production of Salix species can approach $20 \mathrm{Mg}$ of woody dry matter per hectare. Once planted, it provides yields for about 25-30 years. Furthermore, it was estimated that the mean yield of dry willow biomass achieved in Poland is approx. $8.5 \mathrm{Mg} \mathrm{ha}^{-1} \mathrm{y}^{-1} \mathrm{~d}$.m. [6]. It was also found that 0.5 ha of willow (Salix viminalis) cultivation can supply any farm with fuel throughout the year [2]. In biomass production from willow for energy purposes, an important role is played by the density of plants per area unit. Research results conducted by different authors $[7,8]$ indicate that the optimum plant density should be from 15,000 to 25,000 stem cuttings per ha and depend on habitat conditions and the willow variety. Based on the review of previous research, it was concluded that in Poland, the cultivation of new willow clones in the SRC system (short rotation coppice) on former agricultural land should be at a density of about 20,000 cuttings ha ${ }^{-1}$ and harvested in three-year cycles [6]. Moreover, the willow has higher calorific values $\left(19 \mathrm{MJ} \cdot \mathrm{kg}^{-1}\right)$ than other energy crops under the conditions of the Polish climate (Table 1). Although this value does not match the value of hard coal, which is $21 \mathrm{MJ} \cdot \mathrm{kg}^{-1}$, the willow is nevertheless a viable alternative energy source for heating purposes [9]. Furthermore, when assessing the calorific value, the percentage of ash after biomass combustion is an important aspect. It has been estimated that this should not exceed 1.5 percent. This value for the willow is around 1.10 percent and thus meets the requirements. It should be noted that for other energy crops such as giant miscanthus or Jerusalem artichoke, this value is exceeded up to four times (Table 1).

Table 1. Energy crop parameters [9].

\begin{tabular}{ccc}
\hline Energy Crop & Calorific Value $\left[\mathbf{M J} \cdot \mathbf{k g}^{\mathbf{- 1}}\right]$ & Ash Content $[\%]$ \\
\hline Energy willow & 19.23 & 1.1 \\
Tuberous sunflower & 15.31 & 5.36 \\
Miscanthus giganteus & 16.28 & 6.89 \\
\hline
\end{tabular}


Willows have a high demand for nutrients, and adequate soil moisture promotes the tree's movement and uptake of these nutrients. One way of meeting willow requirements is to provide nutrients by fertilising with municipal sewage after pre-treatment. This is particularly applicable on land that does not directly include food or fodder crops [10]. It should be mentioned that willow stands significantly reduce nitrogen and phosphorus concentrations in wastewater. According to Börjesson [11], this value is even 75-90\%. Using wastewater to irrigate willow crops can significantly increase yield and biomass. Furthermore, it also reduces the risk of groundwater pollution and eutrophication of surface waters through the trees' partial uptake of nitrogen and phosphorus. The use of willow as a natural filter for wastewater treatment is an excellent way to clean the environment while increasing biomass production without using additional costs associated with (e.g., fertilization). Another factor in preferring this type of management is the reduction of natural water resources under climate change conditions in favour of using water from municipal [12] or agricultural wastewater [13].

The main factor limiting the growth of energy crops, including the willow, is water availability. This is especially true in regions with temperate climatic conditions, where insufficient rainfall limits biomass growth even with high nitrogen fertilization [14]. In the period of the maximum increase of plant mass (from June to August), the willow reacts particularly to the course of weather conditions. Precipitation and moderately high temperature in this time have a positive effect on biomass yields, while drought may cause a decrease in yields even by 50\% [15]. Plant water consumption depends mainly on the species, the yield obtained and the meteorological conditions, and the length of the growing season [16]. To quantify trees water use (including willow), methods such as Bowen ratio energy balance system, Eddy covariance, and plant water flow (SF) evaluation techniques are used. SF of willow shows diurnal and seasonal variability. Air temperature is the main factor controlling the seasonal variation of SF. The highest water use by willow occurs in May, June, July, August, and September [17]. The willow's groundwater use also depends on the soil's depth, the plant's root system structure, and the soil type. The willow has a deep and well-developed root system, allowing it to use shallow groundwater, unlike field crops usually supplied with water stored in the aeration zone [18]. The range of optimum groundwater table under different soil conditions for willow cultivation is wide and between 1 and $3 \mathrm{~m}$. The increase in willow yields is mainly related to the enhancement of transpiration and the correct ratio between water and air in the soil [19]. The measured transpiration rates for willow are among the higher values compared to other cultivated trees. This is partly due to the fact that the willow is a highly hydrophilic plant that requires high transpiration for biomass production [20]. Despite willow's high water use efficiency (6.3 $\mathrm{g}$ dry biomass per $\mathrm{kg}$ transpired water), researchers note that water availability is a critical factor shaping willow short-rotation forestry [21]. Therefore, it is crucial to carry out research on willow water management and the possibilities of meeting its water needs.

This study aims to determine the water requirements of willow in western Poland. To check whether the water needs of willow are fulfilled in this region, an analysis of the course of climatic conditions and precipitation deficit values was carried out. The hypothesis that the water needs of willow differ between the three analyzed voivodships (Lubusz, Lower Silesian, and West Pomeranian) was considered in this study. Also, trends in changes in water needs were determined. Estimating water needs based on current climatic conditions is essential in appropriate crop management of this plant in this part of the country. This is one of the few studies on the water needs of willow cultivation in western Poland. The conducted research will be a valuable practical guideline for cultivating this plant for farmers and growers.

\section{Materials and Methods}

The assessment of water needs of willow (Salix L.) was carried out for three voivodships located in western Poland, namely the Lower Silesian, Lubusz, and West Pomeranian voivodships. Calculations were based on data obtained from meteorological stations located 
in the largest cities of each province (i.e., for the Lower Silesian voivodship from Wrocław, for the Lubusz voivodship from Zielona Góra, and the West Pomeranian voivodship from Szczecin (Figure 1)).

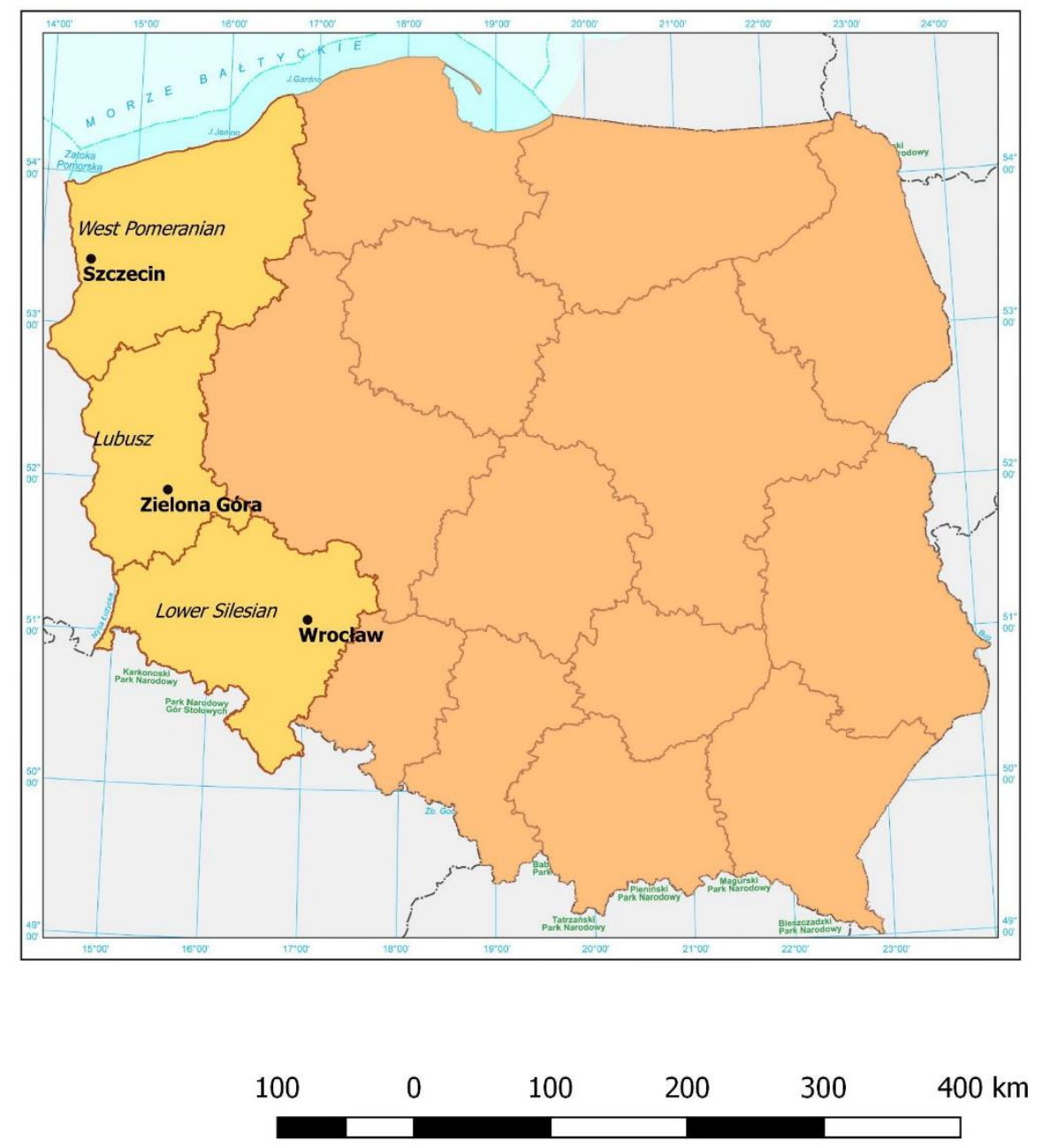

Figure 1. The location of the analyzed voivodships and meteorological stations.

The analysis was carried out for the years from 1981 to 2010. The calculations were made for the growing season lasting in the studied area from the third decade of May (21 May) to the end of October. Based on meteorological data, the reference evapotranspiration (ETo) was determined. ETo is an agrometeorological parameter essential in irrigation planning and management [22]. ETo was calculated using the Blaney-Criddle (B-C) Formula (1) modified by Żakowicz [23] for the conditions of Poland. In this study, equation B-C was chosen to estimate ETo due to the limited availability of meteorological data (only monthly temperature values for the period from 1981 to 2010 are accessible). FAO Irrigation and Drainage Paper No. 24 'Crop water requirements' [24] suggests using the Blaney-Ciddle formula when only air temperature data are available [25]. The B-C formula is commonly used to estimate evapotranspiration with a limited number of available meteorological parameters. This is confirmed by several studies in various world areas [26-28].

$$
\mathrm{ETo}=\mathrm{n} \times[\mathrm{p} \times(0.437 \times \mathrm{t}+7.6)-1.5]
$$

where:

ETo = reference evapotranspiration $(\mathrm{mm})$;

$\mathrm{n}$ = number of days in the month; 
$\mathrm{p}$ = evaporation coefficients according to Doorenbos and Pruitt [24] for months and latitude determined from the tables;

$\mathrm{t} \quad=$ monthly mean air temperature $\left({ }^{\circ} \mathrm{C}\right)$.

Crop (potential) evapotranspiration was then estimated with equation (2). This method is widely used in scientific research [29-32]. Moreover, this equation is also used to calculate crop transpiration in the AquaCrop model developed by the Land and Water Division of FAO [33].

$$
\mathrm{ETp}=\mathrm{ETo} \times \mathrm{kc}
$$

where:

$\mathrm{ETp}=$ crop (potential) evapotranspiration $(\mathrm{mm})$;

ETo = reference evapotranspiration $(\mathrm{mm})$;

$\mathrm{kc}=$ crop coefficient defined as the quotient of evapotranspiration measured in conditions of sufficient soil moisture and reference evapotranspiration (Figure 2) [34].

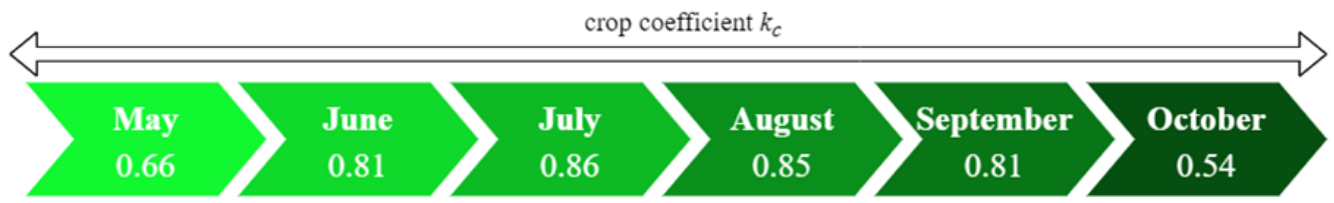

Figure 2. Crop coefficient for the Blaney-Criddle equation for willow depending on the month [34].

The final calculation stage determined the precipitation deficit using Ostromecki's formula (3) $[35,36]$. The rainfall deficit determines the difference between the sum of evapotranspiration of plants and the sum of precipitation. Therefore, by estimating the precipitation deficit, it is possible to determine to what extent plants' water needs are met by precipitation, how much water is lacking, and what amount should be supplied to crops for adequate growth. Rainfall deficit assessments were made for the occurrence probability of the normal years (N50\%), medium dry years (N25\%), and very dry years (N10\%).

$$
\mathrm{Np} \%=\mathrm{Ap} \% \times \mathrm{ETp}-\mathrm{Bp} \% \times \mathrm{P}
$$

where:

$\mathrm{Np} \%=$ precipitation deficit at the probability occurrence $\mathrm{p} \%\left(\mathrm{~mm}_{\text {period }}{ }^{-1}\right)$;

ETp $=$ average multi-year amount of evapotranspiration in the analyzed period $(\mathrm{mm}$ period $\left.^{-1}\right)$;

$\mathrm{P}=$ multi-year average amount of precipitation in the analyzed period $\left(\mathrm{mm} \mathrm{period}^{-1}\right)$; $\mathrm{Ap} \%$ and $\mathrm{Bp} \%=$ numerical factors characterizing the variability of evapotranspiration and precipitation for a given meteorological station.

The obtained results were statistically analyzed in R and Microsoft Excel environments. They aimed to determine the tendency of changes in the water needs of willow and significant differences in the results for individual voivodeships. ANOVA analysis of variance was used to find significant differences in water needs between the three voivodeships, preceded by Shapiro-Wilk tests and Bartlett's test for equality of variance. The analysis considered the following hypothesis:

Hypothesis 1 (H1): the water needs of willow do not differ between voivodships.

The linear correlation coefficient (r) method, widely used and proven in many studies, was used to determine the trend of changes in water needs.

\section{Results}

The results of willow ETp for individual growing seasons (third decade of May to the end of October) in the years from 1981 to 2010 were analyzed. The calculated values for 
each of the three provinces were compared to precipitation in the growing season. The analysis for the West Pomeranian voivodship showed that only in two years, 1996 and 2007 , precipitation values $(P)$ were higher than water needs (ETp). Therefore, it can be concluded that for this region, the course of climatic conditions in the studied period is unfavorable concerning the water needs of willow (Figure 3). The highest ETp values were estimated for 2006 and amounted to $442 \mathrm{~mm}$. At the same time, the precipitation reached $253 \mathrm{~mm}$. The lowest rainfall values were recorded in 1982-1983 and were about 162-174 mm. However, it should be noted that this was at the same time also in the period when the greatest differences between ETp and $P$ occurred, amounting to 262 and $247 \mathrm{~mm}$, respectively. Large differences were observed in $1992(221 \mathrm{~mm})$ and $1994(209 \mathrm{~mm})$. The standard deviation (SD) value for precipitation in the West Pomeranian province in 19812010 was 75.1. For the same period, the SD of water needs reached 13.6. Other statistical characteristics are presented in Table 2.

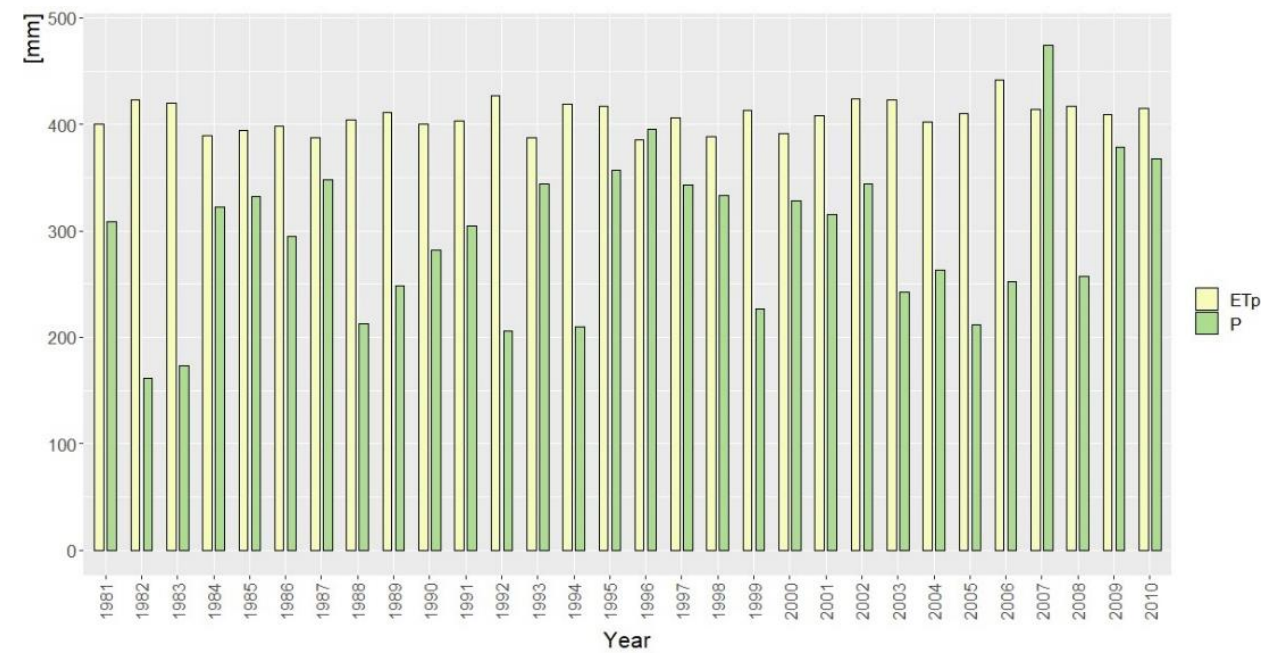

Figure 3. Precipitation $(P)$ and water needs (ETp) in the growing season (third decade of MayOctober) in 1981-2010 in the West Pomeranian voivodeship (SD of $P=75.1$, SD of ETp $=13.6$ ).

Table 2. Statistical characteristics of willow water needs (ETp) and precipitation during 1981-2010 for each province.

\begin{tabular}{ccccccc}
\hline \multirow{2}{*}{ Specification } & \multicolumn{2}{c}{ West Pomeranian } & \multicolumn{2}{c}{ Lubusz } & \multicolumn{2}{c}{ Lower Silesian } \\
\cline { 2 - 7 } & $\boldsymbol{P}$ & ETP & $\boldsymbol{P}$ & ETP & $\boldsymbol{P}$ & ETP \\
\hline Maximum [mm] & 538 & 442 & 544 & 444 & 522 & 429 \\
Minimum [mm] & 207 & 385 & 189 & 377 & 251 & 378 \\
Mean [mm] & 365 & 408 & 381 & 405 & 384 & 402 \\
Standard Deviation SD & 75.1 & 13.6 & 93.0 & 17.4 & 85.7 & 12.6 \\
\hline
\end{tabular}

The situation was slightly better in Lubusz voivodship, where precipitation was greater than water needs in the growing seasons in the analyzed 5 out of 30 years (Figure 4). This group includes 1981, 1985, 1993, 1996, and 1998. The highest precipitation values occurred during the growing season in 1981 and amounted to $463 \mathrm{~mm}$, while the lowest of $150 \mathrm{~mm}$ was recorded a year later (1982). The standard deviation of precipitation for the years analyzed reached 93 . The difference in the driest year between $P$ and ETp was $249 \mathrm{~mm}$. However, it should be noted that this was not the highest value for the analyzed multi-year period. The greatest difference between precipitation and water needs in the West Pomeranian Voivodship was recorded in 1992, and it amounted to $278 \mathrm{~mm}$. The maximum value of water needs was in 2006 and amounted to $444 \mathrm{~mm}$. The standard deviation of the ETp in the analyzed years was 17.4 (Table 2). 


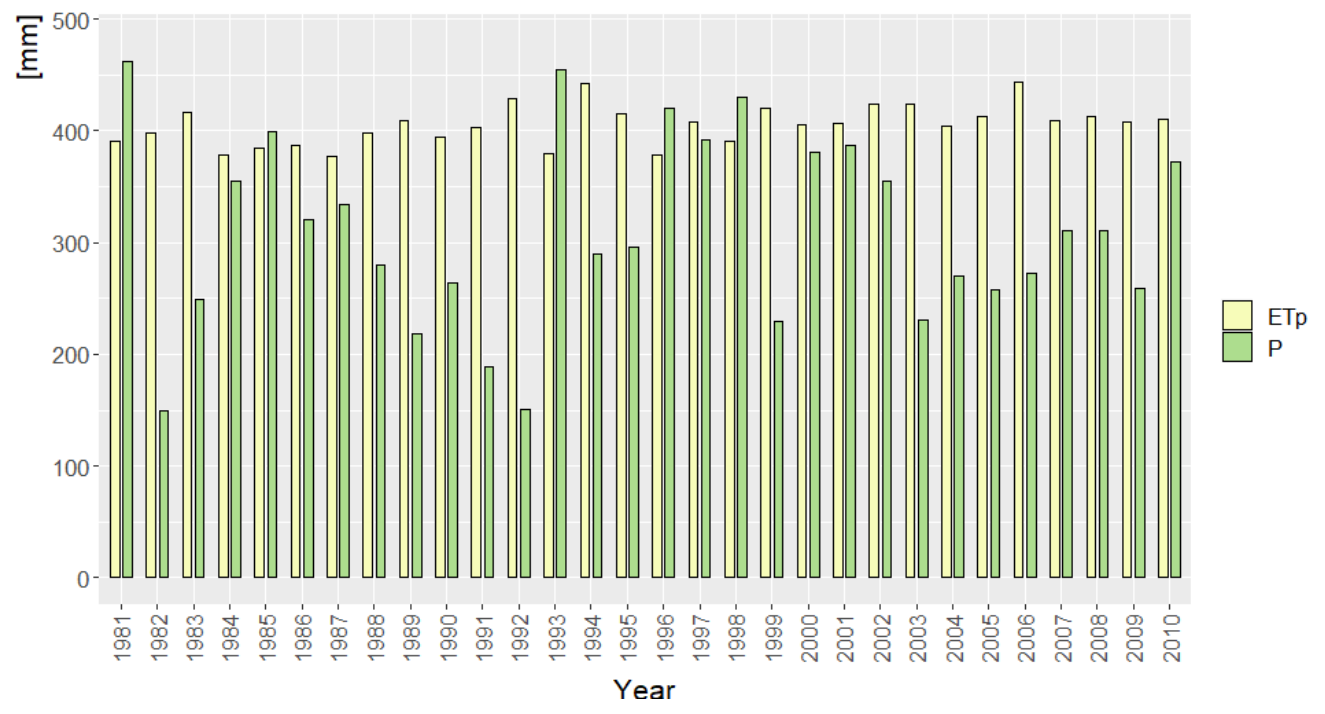

Figure 4. Precipitation $(P)$ and water needs (ETp) in the growing season (third decade of MayOctober) in 1981-2010 in the Lubusz voivodeship (SD of $P=93$, SD of ETp =17.4).

Among the analyzed regions, Lower Silesian voivodship had the highest number of vegetation seasons in which precipitation exceeded water needs. In this case, positive values were recorded in 6 out of 30 years, more precisely in 1981, 1986, 1995, 1997, 2001, and 2009 (Figure 5). The year 1981 was also in this region characterized by the lowest precipitation in the vegetation season, amounting to $179 \mathrm{~mm}$. It was also the year when the difference between precipitation and ETp was the greatest and amounted to $233 \mathrm{~mm}$. A relatively large difference $(220 \mathrm{~mm})$ was re-recorded in 1994 . The highest precipitation values were reached in 1997 with $522 \mathrm{~mm}$. For the 30 years analyzed, the SD of precipitation was 85.7 , while for water needs, the SD was 12.6 (Table 2).

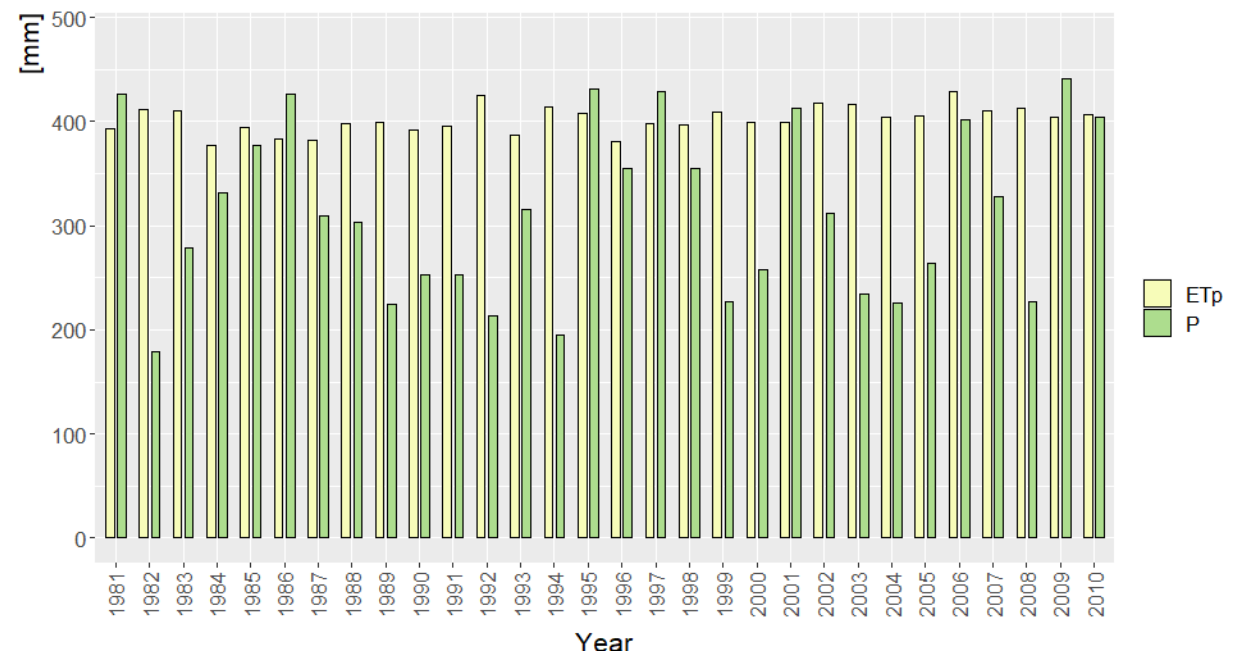

Figure 5. Precipitation $(P)$ and water needs (ETp) in the growing season (third decade of MayOctober) in 1981-2010 in the Lower Silesian voivodeship (SD of $P=85.7$, SD of ETp = 12.6).

Analyzing the climatic conditions during 30 years (1981-2010) in the growing seasons for the three provinces, it can be seen that in most years in all voivodships the ETp values were higher than $P$. Only in a few years the situation was reversed, and interestingly for each province, there were different years in most cases. Looking at the graphs (Figures 3-5), one can conclude that conditions were unfavorable for willow cultivation in most years. A potential solution to the problem of large differences between precipitation and ETp values for Salix cultivation could be the application of an adequate irrigation rate with treated 
wastewater. Many scientific studies underline that willow is a plant for which this type of irrigation can benefit and contribute to plant development [10]. Wastewater irrigation could also be a favourable solution in the case of Poland due to the country's limited water resources.

As part of the analyses, mean values of monthly water needs were determined for each of the studied voivodships (Lower Silesian, Lubusz, and West Pomeranian) for the measurement periods in 1981-2010 (Figure 6). It was observed that the beginning of the growing season (3rd decade of May) is characterized by relatively low water needs resulting from lower temperature and limited evaporation. These values are 18 to $25 \mathrm{~mm}$ for the Lower Silesian and the West Pomeranian voivodships. In the case of Lubusz Voivodeship, the maximum value of water requirements in the third decade of May is $47 \mathrm{~mm}$. Low values of water needs are also noted at the end of the growing season (October). Moreover, the highest water needs are observed in June, July, and August. They resulted from plant growth enhancement and increased evaporation.

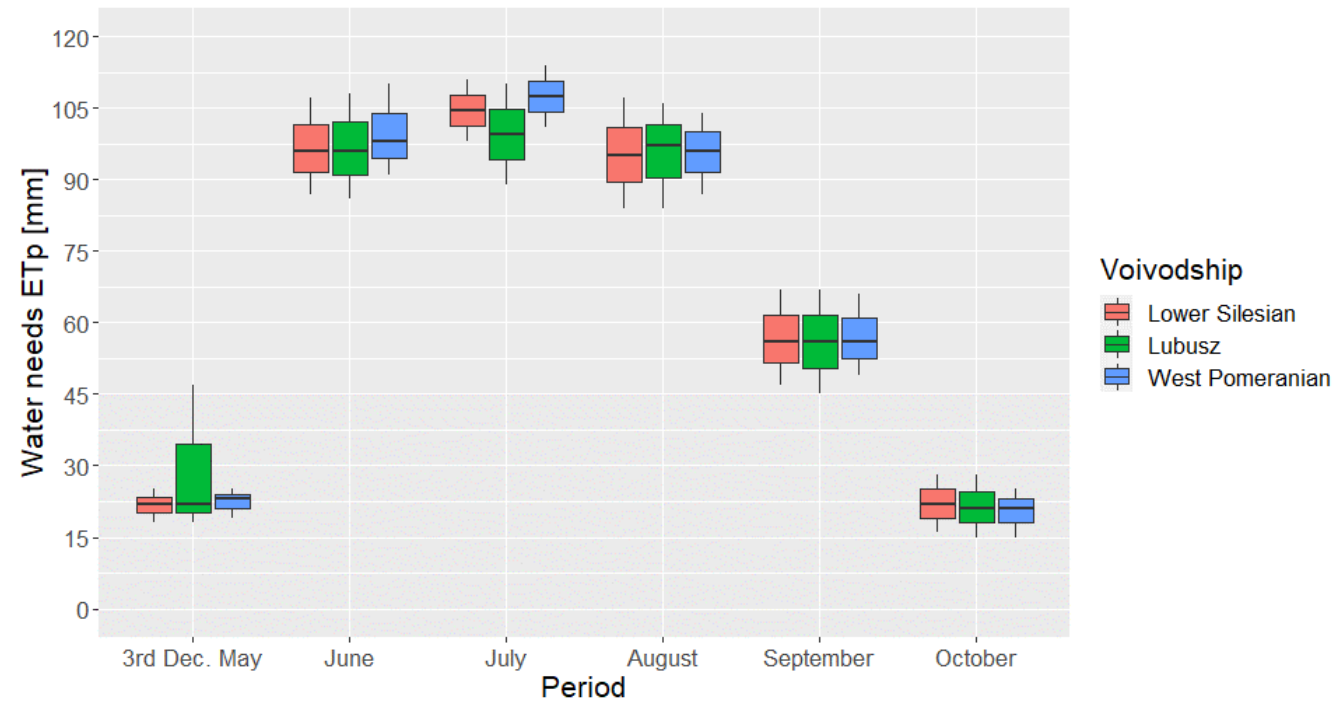

Figure 6. Water requirements (ETp) in the growing season calculated for individual voivodeships in 1981-2010.

The highest values of standard deviation (SD) characterizing the variability of water demand also occurred in the summer months (i.e., June, July, August, and September (Table 3)). Even though the value of the average potential evapotranspiration of willow ETp for the three voivodeships was similar in the whole growing season and amounted to $402-408 \mathrm{~mm}$, there were differences in the value of the SD index. Among the studied voivodeships, Lubusz had the highest monthly SD index values ranging from 3.0 to 9.3. In the two other voivodeships, the values were similar. The highest SD value was reached in July for Lubusz, and it was 9.3. 
Table 3. Statistical characteristics of willow water needs in the period 1981-2010 determined as $\mathrm{ETp}[\mathrm{mm}]$.

\begin{tabular}{ccccccccc}
\hline \multirow{2}{*}{ Specification } & \multicolumn{7}{c}{ Period } \\
\cline { 3 - 9 } & & 3rd Dec.V & VI & VII & VIII & IX & X & 3rd Dec.V-X \\
\hline \multirow{3}{*}{ Mean } & WP & 22 & 98 & 114 & 96 & 57 & 21 & 408 \\
& L & 23 & 97 & 111 & 97 & 57 & 22 & 405 \\
& LS & 22 & 97 & 111 & 94 & 56 & 22 & 402 \\
\hline \multirow{3}{*}{ Standard Deviation (SD) } & WP & 1.5 & 4.8 & 7.4 & 4.3 & 3.9 & 2.7 & 13.6 \\
& L & 4.8 & 5.8 & 9.3 & 5.3 & 5.2 & 3.0 & 17.4 \\
& LS & 1.4 & 5.1 & 6.7 & 4.4 & 4.3 & 2.8 & 12.6 \\
\hline \multirow{3}{*}{ Coefficient of Variation (VC [\%]) } & WP & 6.8 & 4.9 & 6.5 & 4.5 & 7.0 & 13.1 & 3.3 \\
& L & 21.0 & 6.0 & 8.4 & 5.5 & 9.2 & 14.1 & 4.3 \\
& LS & 6.2 & 5.3 & 6.1 & 4.6 & 7.6 & 12.9 & 3.1 \\
\hline
\end{tabular}

Voivodeship: WP, West Pomeranian; L, Lubusz; LS, Lower Silesian.

Based on meteorological data from 1981-2010 for each analyzed voivodship, the average water needs in the growing season (from the 3rd decade of May to the end of October) were calculated (Figure 7). For the Lubusz Voivodship, average water needs from 30 years were $405 \mathrm{~mm}$, while the median was $407 \mathrm{~mm}$. The maximum value was $444 \mathrm{~mm}$, and the minimum was $377 \mathrm{~mm}$. For the Lower Silesian province, the mean value for the growing season was $3 \mathrm{~mm}$ lower than for the Lubusz vhoivodship and amounted to $402 \mathrm{~mm}$. The minimum value of water needs of this voivodship in the growing season was $378 \mathrm{~mm}$ and a maximum $429 \mathrm{~mm}$. In West Pomeranian voivodship, the average value of water needs was the highest of all three studied voivodships and amounted to $408 \mathrm{~mm}$. The range of values, in this case, was from $385 \mathrm{~mm}$ to $442 \mathrm{~mm}$.

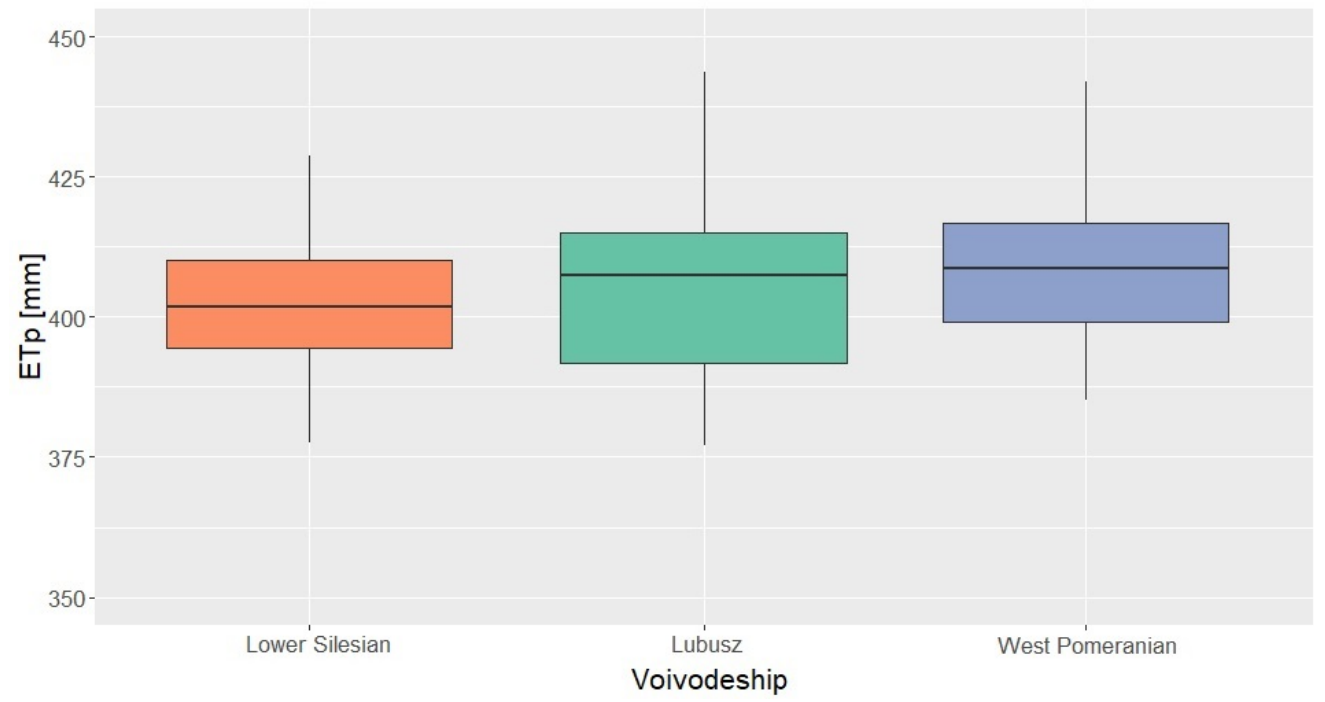

Figure 7. Average water requirements of willow for the analyzed voivodeships during the growing season (3rd decade of May to the end of October) calculated based on data from 1981 to 2010. (SD equaled 12.7, 17.4 and 13.6 for Lower Silesian, Lubusz and West Pomeranian, respectively).

The calculated Etp values for the growing season for each year in the years 1981-2010 in the studied three voivodeships were also subjected to statistical analyses in $\mathrm{R}$ to check whether there were significant differences between the provinces. First, for a data sequence for each voivodship, the hypothesis of normality of distribution was verified using the Shapiro-Wilk test. A significance level of $\alpha=0.05$ was assumed. The obtained results for the probability level ( $p$-value) were greater than 0.05 . Based on this $(p$-value $>\alpha)$, it was concluded that the assumption of normality of distribution is fulfilled (Table 4). Next, 
Bartlett's test for equality of variance was performed. Also, a significance level was taken as $\alpha=0.05$. A $p$-value of 0.1811 was obtained, greater than 0.05 ( $p$-value $>\alpha$ ). Therefore, it was concluded that at a significance level of $\alpha=0.05$, there are no grounds to reject the hypothesis stating the equality of variance of water needs in the growing season for the three provinces. Therefore, further analyses can be carried out.

Table 4. $P$-value obtained after Shapiro-Wilk test.

\begin{tabular}{cc}
\hline Voivodeship & $p$-Value \\
\hline West Pomeranian (WP) & 0.5853 \\
Lubusz (L) & 0.4485 \\
Lower Silesian (LS) & 0.8892 \\
\hline
\end{tabular}

Another analysis performed in the R environment to determine whether there were significant differences between water needs in the individual voivodships was an ANOVA analysis of variance. It included hypothesis H0: the water needs of willow in the analysed provinces do not differ. The significance level was taken as $\alpha=0.05$. The ANOVA analysis resulted in a $p$-value of 0.33 (i.e., greater than $0.05(p$-value $>\alpha)$ ). Therefore, it was concluded that at a significance level of $\alpha=0.05$, there were no grounds to reject the H0 hypothesis. Thus, the values of water requirements in 1981-2010 calculated for the growing season for the three voivodships do not differ statistically significantly. As there was no basis for rejecting the $\mathrm{H} 0$ hypothesis, no further multiple tests were conducted to test the significance of the differences. Post-hoc tests were not performed since, based on ANOVA analysis, they would not show differences between water needs in the analyzed provinces. Therefore, it can be concluded that the whole area of western Poland is characterized by similar water needs in the case of willow.

Analyzing the obtained values of water needs in the studied period compared to precipitation for Lubusz, West Pomeranian, and Lower Silesian voivodships, it can be noticed that water requirements in western Poland are not fulfilled. The precipitation values were lower than the needs in all three voivodships (Figure 8). The most remarkable difference is visible in West Pomeranian voivodship, where the average amount of rainfall in the growing season is $365 \mathrm{~mm}$, and the calculated water needs are $408 \mathrm{~mm}$. In Lubusz and Lower Silesian voivodeships, this difference was lower and ranged from 18-24 mm, almost half as much as in West Pomeranian voivodeships. The standard deviation values for the data are shown in Table 2.

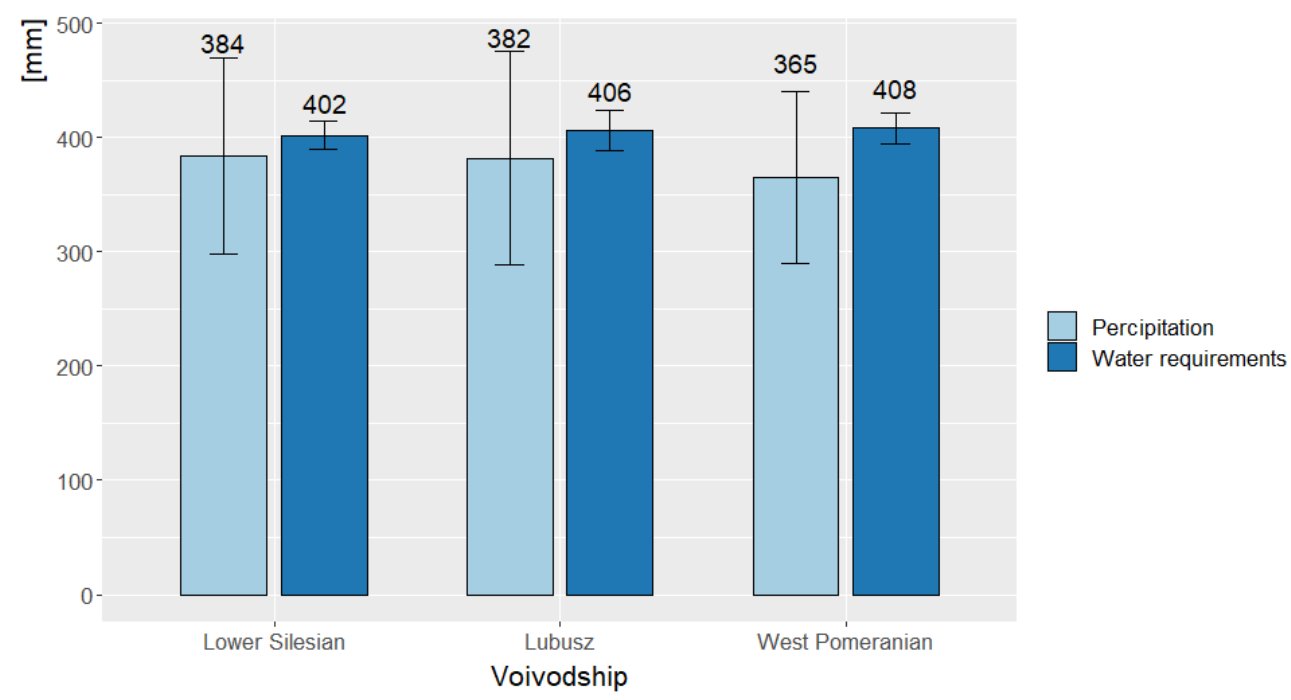

Figure 8. Water needs of willow and average precipitation during the growing season for individual provinces in 1981-2010. 
The estimated water requirements of willow in individual decades (1981-1990, 1991-2000, and 2001-2010) of the 1981-2010 period showed an increasing trend (Figure 9). In Lubusz province in 1981-1990, the water needs were $394 \mathrm{~mm}$ and in 2001-2010 as much as $416 \mathrm{~mm}$. Thus, the needs in this province increased by $22 \mathrm{~mm}$. It was the highest increase in comparison to all three analyzed voivodeships. In Lower Silesian, this increase was $16 \mathrm{~mm}$, and in West Pomeranian $14 \mathrm{~mm}$. In the first analyzed decade of 1981-1990, the highest water requirements for willow were in the West Pomeranian voivodship. They amounted to $403 \mathrm{~mm}$, while the lowest $(394 \mathrm{~mm}$ ) were in the Lubusz voivodship. On the other hand, the Lower Silesian province's lowest value in 2001-2010 of $411 \mathrm{~mm}$. Analysing standard deviation (SD), the highest values in all three regions were recorded for data from the decade 1991-2000. The greatest SD was for Lubusz province and reached 20.53. The lowest SD was estimated for data from 2001 to 2010 in Lower Silesian and earned 8.51 (Table 5).

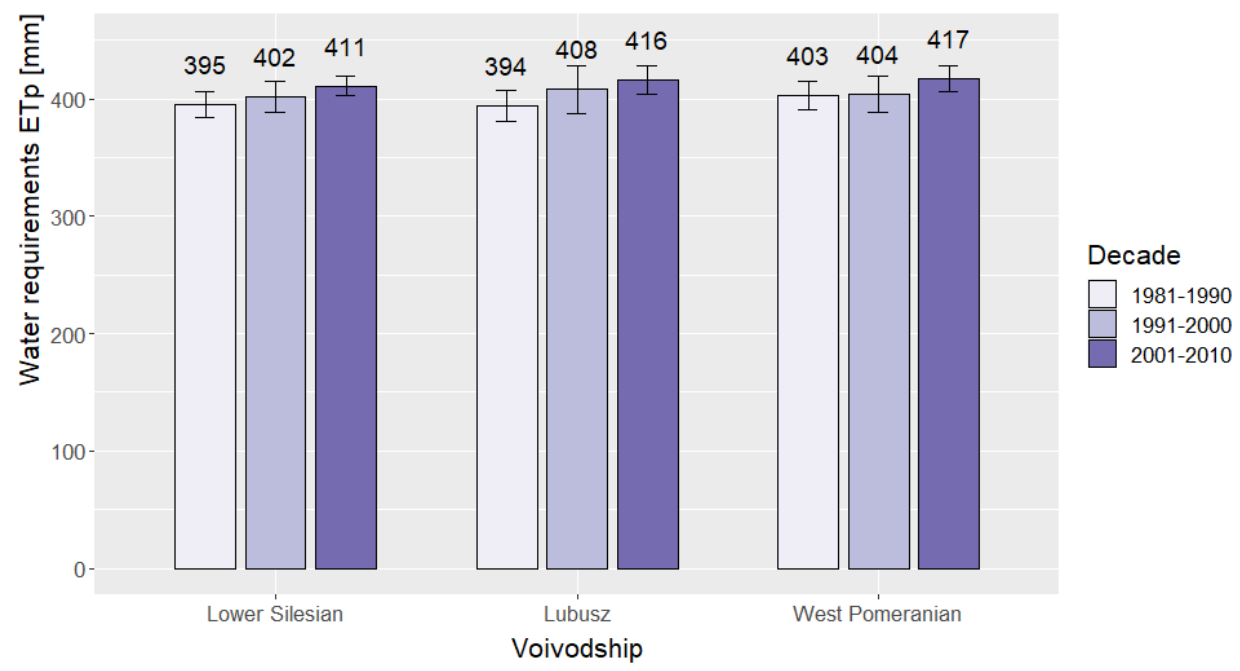

Figure 9. Average water needs of willow in each decade (10-year periods) from 1981 to 2010 for the analyzed voivodeships.

Table 5. Values of standard deviation (SD) for decadal data for each voivodship.

\begin{tabular}{cccc}
\hline \multirow{2}{*}{ Voivodeship } & \multicolumn{3}{c}{ Decade } \\
\cline { 2 - 4 } & $\mathbf{1 9 8 1 - 1 9 9 0}$ & $\mathbf{1 9 9 1 - 2 0 0 0}$ & $\mathbf{2 0 0 1 - 2 0 1 0}$ \\
\hline West Pomeranian & 11.96 & 14.93 & 11.26 \\
Lubusz & 12.87 & 20.53 & 11.95 \\
Lower Silesian & 11.29 & 13.30 & 8.51 \\
\hline
\end{tabular}

\section{Discussion}

The impact of water resources on crops is particularly important in Poland, as Polish water resources are relatively small compared to other European countries. The average total precipitation is about $630 \mathrm{~mm}$ (i.e., $196 \mathrm{~km}^{3}$ per year) [37]. Additionally, water resources in Poland are characterized by high spatial and temporal variability. The recommended way of rational management of limited water resources is retention. It consists in storing water when there is an excess and giving it back to users and the environment in times of shortage. Climate change scenarios indicate that we will increasingly be dealing with extreme weather events that will cause droughts or floods, and therefore appropriate water management is extremely important.

The assessment of climatic water balance for western Poland in the six-month growing season (April-September) indicates the occurrence of large negative differences between precipitation and evapotranspiration values. The increasing likelihood of heatwaves in summer may result in short- or long-lasting droughts that significantly impact crops [38]. 
Also, in this study on willow, large differences between precipitation values and potential evapotranspiration are noticeable (Figures 3-5). It is predicted that the values of the P-E index will change unfavorably in the future, leading to more frequent and more severe summer water stress. Therefore, western and central Poland areas require the necessary protection of agriculture against the negative effects of water shortage during the growing season [39]. Moreover, studies conducted in this paper indicate that plants' water needs will also increase. The determined time trend of the variability of water needs and the linear correlation coefficient (r) showed that in all of the three studied voivodeships, there was a significant tendency for the water needs of willow to increase during the growing season (Table 6). Significant differences were also observed in the summer months (June, July) for Lubusz province. In the Lower Silesian voivodeship, significant differences were also observed in August besides these two months. However, at the same time, no differences were noticed in West Pomeranian.

Table 6. Water needs (mm) of willow in the years between 1981 and 2010 in the provinces of western Poland.

\begin{tabular}{|c|c|c|c|}
\hline \multirow{2}{*}{ Periods } & \multicolumn{3}{|c|}{ Provinces } \\
\hline & West Pomeranian & Lubusz & Lower Silesian \\
\hline \multicolumn{4}{|c|}{ Linear correlation coefficient (r) } \\
\hline 3rd Decade of May & $0.01 \mathrm{~ns}$ & $0.020 \mathrm{~ns}$ & $0.118 \mathrm{~ns}$ \\
\hline June & $0.255 \mathrm{~ns}$ & $0.460 * *$ & $0.450 * *$ \\
\hline July & $0.282 \mathrm{~ns}$ & $0.425 * *$ & $0.382 * *$ \\
\hline August & $0.176 \mathrm{~ns}$ & $0.240 \mathrm{~ns}$ & 0.334 * \\
\hline September & $0.153 \mathrm{~ns}$ & $0.104 \mathrm{~ns}$ & $0.099 \mathrm{~ns}$ \\
\hline October & $0.128 \mathrm{~ns}$ & $0.123 \mathrm{~ns}$ & $0.089 \mathrm{~ns}$ \\
\hline May 21-October 31 & $0.316^{*}$ & $0.469 * * *$ & $0.461^{* *}$ \\
\hline \multicolumn{4}{|c|}{ The tendency of water needs $\left[\mathrm{mm} \cdot\right.$ decade $\left.^{-1}\right]$} \\
\hline May 21-October 31 & 5.0 & 9.4 & 6.7 \\
\hline
\end{tabular}

Analyzing the trend of changes in water needs in the thirty years 1981-2010, it can be observed that for the whole growing season in Lubusz, West Pomeranian, and Lower Silesian voivodeships, the trend is positive (Table 4). The highest is in Lubusz, and it is $9.4 \mathrm{~mm}$-decade ${ }^{-1}$. The values are similar in the following two provinces, and they are $6.7 \mathrm{~mm} \cdot$ decade $^{-1}$ for Lower Silesian and $5.0 \mathrm{~mm} \cdot$ decade $^{-1}$ for West Pomeranian. Analyzing monthly data, the highest increasing tendency of water needs of willow was $4.6 \mathrm{~mm} \cdot$ decade $^{-1}$ in July. On the other hand, slight negative tendencies for all voivodeships were observed in October (Figure 10).

Poland's western and central areas require necessary protection of agriculture against the adverse effects of water shortage during the growing season. The water deficit is evident on light soils with low water retention capacity. Security of crop production against drought is ensured by irrigation. Therefore, irrigation becomes an indispensable element of cultivation in large parts of the country, especially where the climatic water balance is negative (e.g., Wielkopolska, Kujawy), and the soils are characterized by low water retention [39]. The problem of water scarcity is also analyzed in this publication in the context of willow plantations. The precipitation deficits for three voivodeships in the growing season determined by Ostromecki's method [35] are presented in Figure 11. The results of the calculations were shown for three categories of years: very dry years (once per ten years, N10\%), medium dry (once per four years, N25\%), and normal years (once per two years, N50\%). The highest rainfall deficits occurred in the West Pomeranian Province in the very dry year and amounted to $286 \mathrm{~mm}$. Among the three analyzed voivodships, in West Pomeranian voivodship, the deficits were also the highest in average dry years 
(222 $\mathrm{mm}$ ) and normal years $(132 \mathrm{~mm})$. Moreover, the lowest precipitation deficits in the studied period were recorded in Lower Silesian Province. They amounted to $263 \mathrm{~mm}$ for very dry years, $193 \mathrm{~mm}$ for medium dry years, and $99 \mathrm{~mm}$ for normal years.

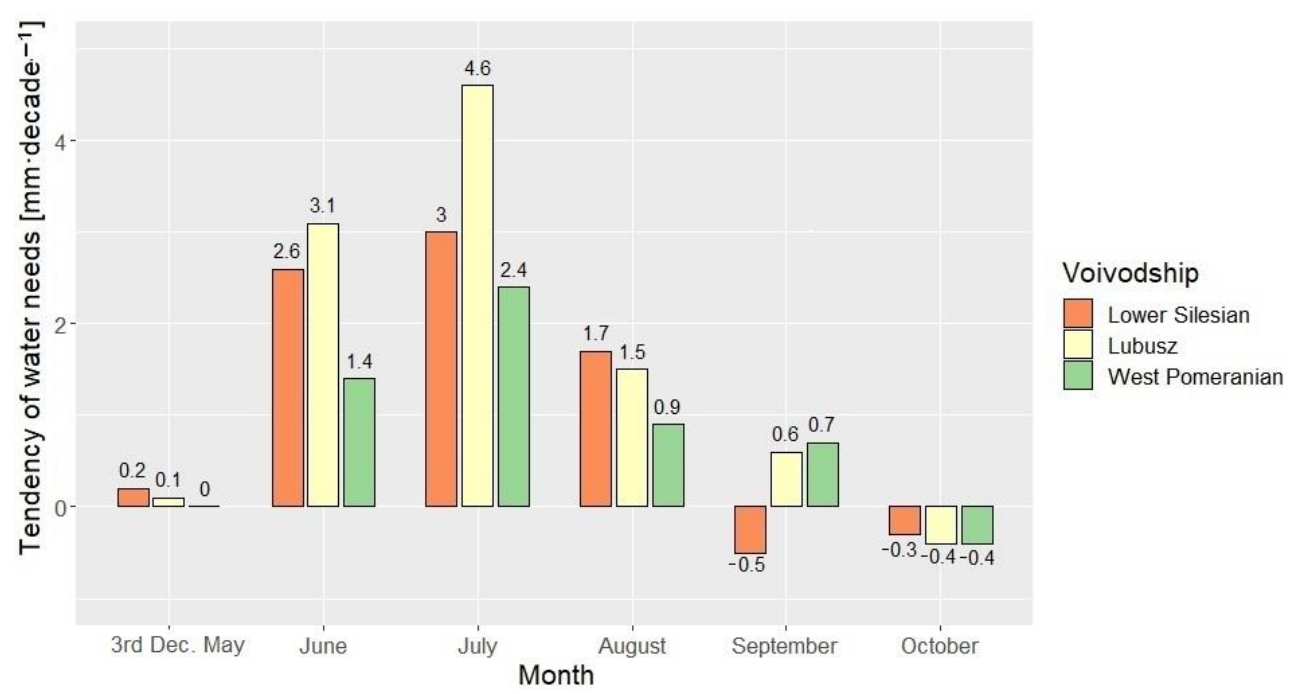

Figure 10. The trend of water needs of willow in each month for the analyzed voivodships.

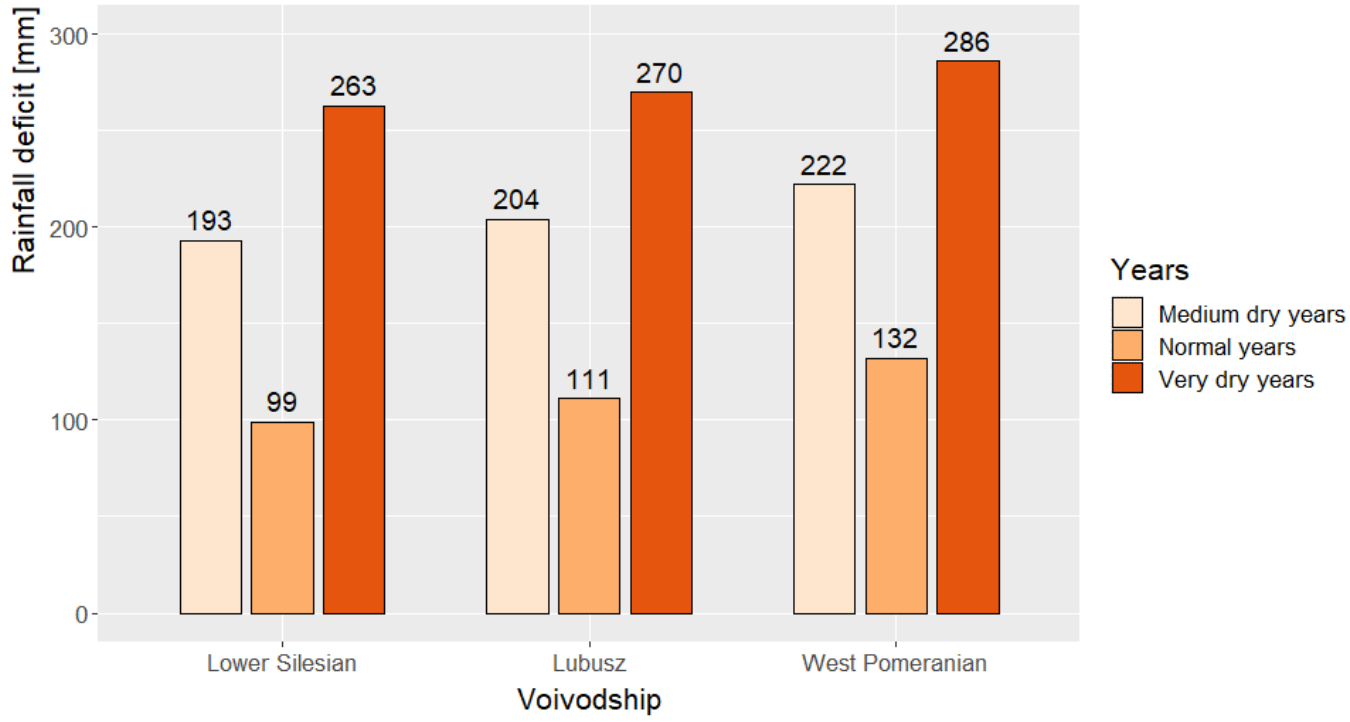

Figure 11. Rainfall deficit for willow cultivation in the analyzed provinces in 1981-2010.

The results confirm a problem of precipitation shortage in western Poland. In combination with its low water resources, it creates a particular threat to agriculture and the production of productive crops. Researchers emphasize that the decision on the location of energy crops with a high share in the catchment should take into account the water needs of energy crops, as their cultivation can significantly affect water balance parameters [40]. The analyses carried out on water need help to determine the potential of a region for willow cultivation. Published scientific articles note the potential of relatively large areas of marginal land and fallow grounds in Poland as suitable sites for willow growth. It should be noted that fallow grounds constitute as much as $10 \%$ of shares of arable lands [41]. Research carried out by scientists shows that in the management of fallow and uncultivated land in Poland for willow weed cultivation, the amount of energy obtained would be 3083 TJ. Moreover, it was shown that one of the voivodeships with the largest potential energy resource is the Lower Silesian voivodeship analyzed in this paper (with a volume of 386 TJ) [42]. Subsequent estimations carried out assuming willow cultivation on the 
total fallow area in Poland in 2014 showed that the energy value of willow wood dry mass would be $138,285,528 \mathrm{GJ} \cdot \mathrm{yr}^{-1}$. Moreover, the dry wood mass for the whole country would be $7,128,120 \mathrm{t} \cdot \mathrm{yr}^{-1}$. The ecological effects of obtaining energy willow biomass for heating purposes were also estimated in these analyses. It was found that as a result of this practice, nitrogen oxide emissions could potentially be reduced in Poland by 26,274 tons per year, carbon dioxide emissions by 13,828,553 tons and sulphur dioxide emissions by about 103,714 tons per year [43]. Therefore, it can be concluded that growing willow on fallow land and harvesting it for use would be a potentially positive measure in the face of climate change and the need to reduce greenhouse gases. Moreover, it would allow meeting the objectives of the European Union policy on greenhouse gas reduction.

Moreover, studies conducted in Poland on willow cultivation in a short rotation woody crops (SRWC) system (of three- to four-year rotation) and Eko-Salix systems (five-year rotation) have shown that the energy gain obtained is even 20 times higher than the inputs needed to run the plantation and harvest the willow biomass [44]. Therefore, this shows that willow cultivation benefits the climate, environment, and economic context. All of these studies support Poland's high potential for this type of cultivation. As Jadczyszyn et al. [45] estimated, the potential area of willow cultivation for energy purposes in Poland amounts to $9541 \mathrm{~km}^{2}$ or $4.6 \%$ of agricultural land. However, this analysis did not cover soils with the highest production potential belonging to the wheat and very good rye complexes and the weakest, too dry soils of the very weak rye complex. It also excluded mountain areas, protected areas and areas with annual precipitation $<550 \mathrm{~mm}$. For the West Pomeranian voivodship, the estimated potential area for willow cultivation amounted to $1094 \mathrm{~km}^{2}(6.5 \%$ of agricultural land), for the Lubusz voivodship $534 \mathrm{~km}^{2}(6.5 \%$ of agricultural land) and the Lower Silesian voivodship $883 \mathrm{~km}^{2}$ (6.8\% of agricultural land) [45]. Thus, it can be concluded that these provinces not only do not differ concerning the water needs of willow (as shown in this paper) but also the potential area under willow cultivation is similar for the percentage of agricultural land in the given voivodship (it is about $6.5-6.8 \%$ of the agricultural land of the voivodship). The research carried out in this study has shown that in the area of the three voivodships of western Poland, there are no significant differences in the water needs of willow estimated for the growing season between 1981 and 2010. Lack of significant differences in the obtained ETp values results most probably from the course of air temperatures in the analyzed period in the voivodships. The used Blaney-Criddle formula is based on air temperature, and hence the data strongly affect the obtained results. However, it should be noted that the use of the B-C formula in this study captured an extremely important trend, namely the increase of water needs of willow. This is due to the fact that the predicted climatic changes under Polish conditions include an increase in air temperature, which affects the growth of plants' water needs.

The water requirements of willow estimated in the paper showed the current unfavorable state of conditions for the cultivation of this plant in western Poland. To obtain the largest possible biomass for energy purposes, providing the willow plant with optimal water conditions is crucial. World research papers have increasingly focused on water management in crops and estimated the necessary amount of water required for adequate irrigation. It is also essential to carry out studies considering the impact of climate change on plants' water needs [46]. Increasingly, research work is being conducted to model crop water requirements and the necessary amount of irrigation water under different climate change scenarios [30,47]. Previous analyses show that climate change has an impact on irrigation water requirements. Furthermore, irrigation demand will increase for many crops due to climate change [48].

Worldwide research indicates the need for precise estimation of plant water requirements. When making such calculations, it is crucial to use appropriate kc coefficients. Measurements conducted for Peach-leaf willow (Salix amygdaloides) in the Platte River basin in central Nebraska, USA, contributed to the development of crop evapotranspiration coefficient (KcET) curves for this cultivar [49]. However, it should be remembered that the water needs of willow depend on climatic conditions. In a study conducted on Salix 
gooddingii grown in restoration plots in three irrigation districts on the Lower Colorado River, reference crop evapotranspiration (ETo) values ranged from 1890 to $1969 \mathrm{~mm} \cdot \mathrm{yr}^{-1}$. For the same sites, irrigation requirement was estimated from 1817 to $1962 \mathrm{~mm} \cdot \mathrm{yr}^{-1}$ [50]. Evapotranspiration (ET) values were also evaluated for wetlands and the willow variety Salix miyabeana. From May to October, the average evapotranspiration rate in eastern Canada was $22.7 \mathrm{~mm} \cdot$ day $^{-1}$ [51]. Therefore, it can be concluded that the estimation of ETp for willow in this study is fundamental in the context of its proper cultivation, and these analyses fit into the trend of global research. Moreover, this study fills a gap in science concerning the determination of the water needs of this plant for the conditions of western Poland. This is one of the few studies on this subject for this region.

Scientists emphasize that the willow is not a demanding plant in cultivation conditions. Furthermore, it has been noted that willow also shows salt tolerance, which has been defined as sensitive to moderately tolerant [52]. Moreover, it has been demonstrated that irrigation of willow with stormwater up to $1625 \mathrm{mg} \mathrm{Cl}$ had no short-term effect on biomass accumulation and evapotranspiration [53]. All of these measurements indicate that willow has a high tolerance to different growing conditions. However, it should be remembered that it is a plant that needs an adequate amount of water for optimal growth. Soil water availability is one of the determinants of willow growth in montane riparian communities in the USA [54]. High available water content (AWC) values were also the most critical determinant of willow yield in the Danish area. AWC had a much greater effect on yield than precipitation, radiation sum, and region [55]. The Swedish researchers found that water is critical for the excellent profitability of willow short-rotation forestry [56]. In addition, studies have shown that the Carolina Willow (Salix caroliniana) seeds in saturated soils kept moist by capillarity had the highest germination capacity [57]. The research also included estimating factors affecting aboveground biomass allocation and water storage ratio in alpine willow shrubs. It was observed that relative water storage allocation was significantly affected by species types [58].

The analyses carried out in this paper have shown that water needs of willow in Poland have an increasing tendency year by year. Due to the ongoing climatic changes, the occurrence of drought periods, and thus precipitation deficits, it will be more and more challenging to fulfill them. It may not be possible to supply the appropriate amount of rainwater necessary for irrigation during drought periods. However, it should be remembered that willow is a plant that can also be successfully irrigated with wastewater. Worldwide research shows that using willow for energy production is an opportunity to reduce greenhouse gas emissions. It has been found that the biomass of this plant can be a carbon negative or low-carbon energy source with high emissions and energy return on investment. This applies to regions with similar conditions for the plant's growth, transport distances, and infrastructure [59]. Therefore, it is crucial to continue research into willow cultivation to optimize its cultivation and widespread use. Research should include field experiments on different willow cultivation practices and varying water availability. In view of climate change and the need for crop adaptation, all kinds of experiments simulating stress conditions such as drought are desirable. Increasing research and knowledge is extremely important, especially in countries such as Poland, which soon must change their energy policy and drastically reduce coal burning in favour of other alternative energy sources, including biomass.

\section{Conclusions}

The calculations and analyses carried out in this paper determined the water needs of willow and evaluated the current conditions of its cultivation in three voivodships of western Poland: West Pomeranian, Lubusz, and Lower Silesian. The main conclusions of the study are as follows:

1. Estimated water needs for the years between 1981 and 2010 in the growing season (from 3rd decade of May to the end of October) amount on average to $408 \mathrm{~mm}$ for West Pomeranian Voivodeship, $405 \mathrm{~mm}$ for Lubusz Voivodeship, and $402 \mathrm{~mm}$ for Lower 
Silesian Voivodeship. The highest values of water needs can be found in June, July, and August, while the lowest can be found in the third decade of May and October.

2. The analysis of variance (ANOVA) of the willow water needs values for the growing season from 1981 to 2010 did not show significant differences between the voivodeships $(p$-value $=0.33>0.05)$. The hypothesis $\mathrm{H} 0$ stating that the water needs of willow in the analyzed provinces do not differ was not rejected. Therefore, it can be concluded that the whole region shows similar conditions for willow cultivation.

3. Precipitation in the studied area of all three voivodeships was lower than the calculated ETp values in most years. However, in only a few years, precipitation fulfilled the water requirements of willow. Concerning this aspect, the best conditions prevailed in the Lower Silesian voivodship, where rainfall was higher than ETp in 6 years out of the analyzed 30 years.

4. Water needs of willows in the analyzed thirty-year period from 1981 to 2010 generally show an increasing trend. This trend forces growers to manage water appropriately, particularly important given Poland's limited water resources.

5. The highest rainfall deficits are found in the West Pomeranian voivodship and range from 132 to $288 \mathrm{~mm}$, depending on the year, while the lowest values are found in the Lower Silesian. The problem of precipitation shortage is currently one of the major challenges for agriculture in Poland.

The analyses carried out show that similar conditions for willow cultivation characterize West Poland, and its water needs mainly were not fulfilled by precipitation in the period from 1981 to 2010. Based on previous worldwide studies, one should consider trying to apply adequate irrigation with water or irrigation with treated wastewater, which would provide an appropriate amount of water to this plant. At the same time, this measure could contribute to obtaining an adequate or even higher yield. The use of wastewater in Poland for this purpose would also be potentially beneficial due to the relatively small water resources. However, more research should be conducted in Poland to verify this hypothesis. Nevertheless, without estimating the water requirements, it is not possible to use adequate irrigation and carry out further experiments correctly. Therefore, this study provides guidance and encouragement for further research and valuable practical advice for farmers and growers.

Currently, scientists emphasize that due to Poland's limited water resources, the selection of a suitable energy crops should be based on the water needs of the plants [40], which were estimated in this paper for the willow. This research project is one of the few attempts to estimate willow ETp for the climate of western Poland. With the accurate estimation of the water needs of the willow, it will be possible to optimize the cultivation of this plant and thus increase the biomass obtained. With increased biomass, this plant could potentially be a source of renewable energy for Poland, thus speeding up the country's transition away from coal mining. Such an action fits into the climate neutrality policy of the European Union, which is currently one of the priorities to be implemented by member states.

Author Contributions: Conceptualization, R.R., S.R., B.J., W.P. and P.P.; methodology, S.R., R.R., P.P., F.P.-F., H.A.S., J.K., A.F., W.P. and D.W.; validation, A.F., D.W., R.R., P.P., S.R., P.S. and H.A.S.; formal analysis, S.R., J.K., R.R. and B.J.; investigation, R.R., S.R., B.J., W.P., D.L., P.S., F.P.-F. and A.Ł.; writing-original draft preparation, J.K., D.L., P.S., R.R. and S.R.; writing-review and editing, J.K., D.L., P.S., R.R. and S.R; visualization, J.K. supervision, R.R., S.R. and D.L. All authors have read and agreed to the published version of the manuscript.

Funding: This research received no external funding.

Institutional Review Board Statement: Not applicable.

Informed Consent Statement: Not applicable.

Data Availability Statement: Data sharing not applicable.

Conflicts of Interest: The authors declare no conflict of interest. 


\section{References}

1. GUS 2021. Energy, Warszawa. 2021. Available online: https://stat.gov.pl/en/topics/environment-energy/ (accessed on 30 November 2021).

2. Sobczyk, W. Evaluation of harvest of energetic basket willow. Teka Kom. Motoryz. Energetyki Rol. 2011, 11, 343-353.

3. Volk, T.A.; Abrahamson, L.P.; Nowak, C.A.; Smart, L.B.; Tharakan, P.J.; White, E.H. The development of short-rotation willow in the Northeastern United States for bioenergy and bioproducts, agroforestry and phytoremediation. Biomass Bioenergy 2006, 30, 715-727. [CrossRef]

4. Kuzovkina, Y.A.; Quigley, M.F. Willows beyond Wetlands: Uses of Salix L. Species for Environmental Projects. Water Air Soil Pollut. 2005, 162, 183-204. [CrossRef]

5. Heinsoo, K.; Sild, E.; Koppel, A. Estimation of shoot biomass productivity in Estonian Salix plantations. For. Ecol. Manag. 2002, 170, 67-74. [CrossRef]

6. Stolarski, M.J.; Niksa, D.; Krzyżaniak, M.; Tworkowski, J.; Szczukowski, S. Willow productivity from small-and large-scale experimental plantations in Poland from 2000 to 2017. Renew. Sustain. Energy Rev. 2019, 101, 461-475. [CrossRef]

7. Bullard, M.J.; Mustill, S.J.; McMillan, S.D.; Nixon, P.M.I.; Carver, P.; Britt, C.P. Yield improvements through modification of planting density and harvest frequency in short rotation coppice Salix spp.-1. Yield response in two morphologically diverse varieties. Biomass Bioenergy 2002, 22, 15-25. [CrossRef]

8. Wilkinson, J.M.; Evans, E.J.; Bilsborrow, P.E.; Wright, C.; Hewison, W.O.; Pillbeam, D.J. Yield of willow cultivars at different planting densities in a commercial short rotation coppice in the north of England. Biomass Bioenergy 2007, 31, 469-474. [CrossRef]

9. Magazyn Biomasa. Porównanie Roślin Energetycznych Uprawianych w Polsce. 2017. Available online: https://magazynbiomasa. $\mathrm{pl} /$ porownanie-roslin-energetycznych-uprawianych-polsce (accessed on 14 October 2021).

10. Hasselgren, K. Use of municipal waste products in energy forestry: Highlights from 15years of experience. Biomass Bioenergy 1998, 15, 71-74. [CrossRef]

11. Börjesson, P. Environmental effects of energy crop cultivation in Sweden-I: Identification and quantification. Biomass Bioenergy 1999, 16, 137-154. [CrossRef]

12. Perttu, K.L.; Kowalik, P.J. Salix vegetation filters for purification of waters and soils. Biomass Bioenergy 1997, 12, 9-19. [CrossRef]

13. Elowson, S. Willow as a vegetation filter for cleaning of polluted drainage water from agricultural land. Biomass Bioenergy 1999, 16, 281-290. [CrossRef]

14. Mitchell, C.P.; Stevens, E.A.; Watters, M.P. Short-rotation forestry-operations, productivity and costs based on experience gained in the UK. For. Ecol. Manag. 1999, 121, 123-136. [CrossRef]

15. Juliszewski, T.; Kwaśniewski, D.; Baran, D. Wpływ wybranych czynników na przyrosty wierzby energetycznej. Inżynieria Rol. 2006, 10, 225-232.

16. Larsen, S.U.; Jørgensen, U.; Lærke, P.E. Willow Yield Is Highly Dependent on Clone and Site. BioEnergy Res. 2014, 7, 1280-1292. [CrossRef]

17. Yin, L.; Zhou, Y.; Huang, J.; Wenninger, J.; Hou, G.; Zhang, E.; Wang, X.; Dong, J.; Zhang, J.; Uhlenbrook, S. Dynamics of willow tree (Salix matsudana) water use and its response to environmental factors in the semi-arid Hailiutu River catchment, Northwest China. Environ. Earth Sci. 2014, 71, 4997-5006. [CrossRef]

18. Kanecka-Geszke, E. Zużycie wody i plonowanie wierzby wiciowej (Salix viminalis L.) na glebach mineralnych o gospodarce opadowo-retencyjnej. Maszynopis. Praca doktorska 2015, 162.

19. Rydłowski, M. Wpływ poziomu wody gruntowej oraz warunków roku badań nawielkość ewapotransoiracji wierzby wiciowej (Salix viminalis L.) w świetle badań lizymetrycznych. Woda-Sr-Obsz. Wiej. 2016, 16, 73-84.

20. Hall, R.L.; Allen, S.J.; Rosier, P.T.W.; Hopkins, R. Transpiration from coppiced poplar and willow measured using sap-flow methods. Agric. For. Meteorol. 1998, 90, 275-290. [CrossRef]

21. Lindroth, A.; Cienciala, E. Water use efficiency of short-rotation Salix viminalis at leaf, tree and stand scales. Tree Physiol. 1996, 16, 257-262. [CrossRef]

22. Łabędzki, L.; Kanecka-Geszke, E.; Bąk, B.; Słowińska, S. Estimation of Reference Evapotranspiration Using the FAO Penman-Monteith Method for Climatic Conditions of Poland; Institute of Technology and Life Sciences: Falenty, Poland, 2011. Available online: https:/ / www.intechopen.com/chapters/14190 (accessed on 26 December 2021).

23. Żakowicz, S. Podstawy Technologii Nawadniania Rekultywowanych Składowisk Odpadów Komunalnych; SGGW: Warszawa, Poland, 2010.

24. Doorenbos, J.; Pruitt, W.O. Guidelines for Predicting Crop Water Requirements; FAO Irrigation and Drainage Paper 24; Food and Agriculture Organization: Rome, Italy, 1977.

25. Allen, R.G.; Pereira, L.S.; Raes, D.; Smith, M. Crop Evapotranspiration. Guidelines for Computing Crop Water Requirements; FAO Irrigation and Drainage No. 56; Food and Agriculture Organization: Rome, Italy, 1998.

26. Hafeez, M.; Khan, A.A. Assessment of Hargreaves and Blaney-Criddle Methods to Estimate Reference Evapotranspiration Under Coastal Conditions. Am. J. Sci. Eng. Technol. 2018, 3, 65-72. [CrossRef]

27. Heydari, M.M.; Tajamoli, A.; Ghoreishi, S.H. Evaluation and calibration of Blaney-Criddle equation for estimating reference evapotranspiration in semiarid and arid regions. Environ. Earth Sci. 2015, 74, 4053-4063. [CrossRef]

28. Xiong, Y.; Luo, Y.; Wang, Y.; Traore, S.; Xu, J.; Jiao, X.; Fipps, G. Forecasting daily reference evapotranspiration using the Blaney-Criddle model and temperature forecasts. Arch. Agron. Soil Sci. 2016, 62, 790-805. [CrossRef] 
29. Mendez-Costabel, M.; Morgan, A.; Dokoozlian, N.; Thoreson, B.; Clark, B. Remote sensing of irrigation requirements in wine grapes; validation of an energy balance model and potential application of vegetation indices. Acta Hortic. 2014, 1038, $249-254$. [CrossRef]

30. Ewaid, S.H.; Abed, S.A.; Al-Ansari, N. Crop Water Requirements and Irrigation Schedules for Some Major Crops in Southern Iraq. Water 2019, 11, 756. [CrossRef]

31. Łabędzki, L. Susze rolnicze. Zarys problematyki oraz metody monitorowania i klasyfikacji. Woda. Sr. Obsz. Wiej. Rozpr. Nauk. Monogr. 2006, 17, 1-107.

32. Doorenbos, J.; Kassam, A. Yield Response to Water; FAO Irrigation and Drainage Paper 33; Food and Agriculture Organization: Rome, Italy, 1979.

33. Durodola, O.S.; Mourad, K.A. Modelling Maize Yield and Water Requirements under Different Climate Change Scenarios. Climate 2020, 8, 127. [CrossRef]

34. Żyromski, A.; Biniak-Pieróg, M.; Szulczewski, W.; Kordas, L.; Kabała, C.; Gałka, B. Mathematical Modeling of Evapotranspiration of Selected Energy Crops; Wydawnictwo Uniwersytetu Przyrodniczego we Wrocławiu: Wrocław, Poland, 2016; ISBN 978-83-7717-253-7.

35. Rolbiecki, S.; Rolbiecki, R.; Jagosz, B.; Figas, A.; Ptach, W.; Stachowski, P. Irrigation effects of red beet as affected by rainfall in different regions of Poland. In Infrastructure and Environment; Krakowiak-Bal, A., Vaverkova, M., Eds.; Springer: Cham, Switzerland, 2020. [CrossRef]

36. Łabędzki, L.; Bąk, B.; Kanecka-Geszke, E.; Kasperska-Wołowicz, W.; Smarzyńska, K. Związek między suszą meteorologiczną i rolniczą w różnych regionach agroklimatycznych Polski. Woda Sr. Obsz. Wiej. 2008, 25, 137.

37. Ziernicka-Wojtaszek, A.; Kopcińska, J. Variation in atmospheric precipitation in Poland in the years 2001-2018. Atmosphere 2020, 11, 794. [CrossRef]

38. Szwed, M.; Karg, G.; Pinskwar, I.; Radziejewski, M.; Graczyk, D.; Kędziora, A.; Kundzewicz, Z.W. Climate change and its effect on agriculture, water resources and human health sectors in Poland. Nat. Hazards Earth Syst. Sci. 2010, 10, 1725-1737. [CrossRef]

39. Kundzewicz, Z.; Banasik, K.; Błażejewski, R.; Januchta-Szostak, A.; Jokiel, P.; Kochanek, K.; Konieczny, R.; Kutek, K.; Majewski, W.; Nachlik, E.; et al. Alert wodny nr 2-Konieczna jest redukcja ryzyka powodzi i suszy. Gospodarka Wodna 2020, 8, 4-6. [CrossRef]

40. Pierzgalski, E.; Mańk, K. Energy crops in aspect of water resources in Poland. In Agro-Energy for Sustainable Agriculture and Rural Development: Good Practices from Slovakia-Serbia Bilateral Cooperation; Singidunum University, Faculty of Applied Ecology Futura: Belgrade, Serbia, 2016.

41. Jasiulewicz, M. Biomass from willow plantation as a source of renewable energy and reduction of smog emissions. Studia Obsz. Wiej. 2020, 57, 145-153. [CrossRef]

42. Igliński, B.; Cichosz, M.; Skrzatek, M.; Buczkowski, R. Potencjał energetyczny biomasy na gruntach ugorowanych i nieużytkach w Polsce [Energy Potential of Biomass on Uncultivated Lands and Fallows in Poland]. Inżynieria Ochr. Sr. 2018, 21, 79-87. [CrossRef]

43. Gawrońska, G.; Gawroński, K. Metoda szacunku potencjalnych efektów ekologicznych pozyskania energii biomasy drewna wierzby energetycznej na przykładzie Polski. Acta Sci. Pol. Form. Circumiectus 2016, 15, 5-16. [CrossRef]

44. Szczukowski, S.; Tworkowski, J.; Stolarski, M.J.; Krzyzaniak, M. The energy efficiency of willow biomass production in Poland-a comparative study. Pap. Glob. Chang. 2015, 22, 123-130. [CrossRef]

45. Jadczyszyn, J.; Faber, A.; Zaliwski, A. Wyznaczanie obszarów potencjalnie przydatnych do uprawy wierzby i ślazowca pensylwańskiego na cele energetyczne w Polsce. Studia Rap. IUNG-PIB 2008, 11, 55-65.

46. Acharjee, T.K.; Ludwig, F.; van Halsema, G.; Hellegers, P.; Supit, I. Future changes in water requirements of Boro rice in the face of climate change in North-West Bangladesh. Agric. Water Manag. 2017, 194, 172-183. [CrossRef]

47. Zhang, Y.; Wang, Y.; Niu, H. Effects of temperature, precipitation and carbon dioxide concentrations on the requirements for crop irrigation water in China under future climate scenarios. Sci. Total Environ. 2019, 656, 373-387. [CrossRef]

48. Masia, S.; Trabucco, A.; Spano, D.; Snyder, R.L.; Sušnik, J.; Marras, S. A modelling platform for climate change impact on local and regional crop water requirements. Agric. Water Manag. 2021, 255, 107005. [CrossRef]

49. Irmak, S.; Kabenge, I.; Rudnick, D.; Knezevic, S.; Woodward, D.; Moravek, M. Evapotranspiration crop coefficients for mixed riparian plant community and transpiration crop coefficients for Common reed, Cottonwood and Peach-leaf willow in the Platte River Basin, Nebraska-USA. J. Hydrol. 2013, 481, 177-190. [CrossRef]

50. Hartwell, S.; Morino, K.; Nagler, P.L.; Glenn, E.P. On the irrigation requirements of cottonwood (Populus fremontii and Populus deltoides var. wislizenii) and willow (Salix gooddingii) grown in a desert environment. J. Arid. Environ. 2010, 74, 667-674. [CrossRef]

51. Frédette, C.; Grebenshchykova, Z.; Comeau, Y.; Brisson, J. Evapotranspiration of a willow cultivar (Salix miyabeana SX67) grown in a full-scale treatment wetland. Ecol. Eng. 2019, 127, 254-262. [CrossRef]

52. Mirck, J.; Zalesny, R.S. Mini-Review of Knowledge Gaps in Salt Tolerance of Plants Applied to Willows and Poplars. Int. J. Phytoremediation 2015, 17, 640-650. [CrossRef] [PubMed]

53. Mirck, J.; Volk, T.A. Response of three shrub willow varieties (Salix spp.) to storm water treatments with different concentrations of salts. Bioresour. Technol. 2010, 101, 3484-3492. [CrossRef]

54. Gage, E.A.; Cooper, D.J. Constraints on willow seedling survival in a Rocky Mountain Montane floodplain. Wetlands 2004, 24, 908-911. [CrossRef]

55. Larsen, S.; Jaiswal, D.; Bentsen, N.S.; Wang, D.; Long, S.P. Comparing predicted yield and yield stability of willow and Miscanthus across Denmark. GCB Bioenergy 2016, 8, 1061-1070. [CrossRef] 
56. Lindroth, A.; Båth, A. Assessment of regional willow coppice yield in Sweden on basis of water availability. For. Ecol. Manag. 1999, 121, 57-65. [CrossRef]

57. Castro-Morales, L.M.; Quintana-Ascencio, P.F.; Fauth, J.E.; Ponzio, K.J.; Hall, D.L. Environmental Factors Affecting Germination and Seedling Survival of Carolina Willow (Salix Caroliniana). Wetlands 2014, 34, 469-478. [CrossRef]

58. Liu, Z.W.; Chen, R.S.; Song, Y.X.; Han, C.T. Aboveground biomass and water storage allocation in alpine willow shrubs in the Qilian Mountains in China. J. Mt. Sci. 2015, 12, 207-217. [CrossRef]

59. Yang, S.; Volk, T.A.; Fortier, M.-O.P. Willow Biomass Crops Are a Carbon Negative or Low-Carbon Feedstock Depending on Prior Land Use and Transportation Distances to End Users. Energies 2020, 13, 4251. [CrossRef] 